\title{
The Potential of Skin and Bones of Kacang Goat for the Production of Halal Gelatine
}

\author{
Sitti Chadijah ${ }^{1}$, Maswati Baharuddin ${ }^{2}$, Putut Waskito ${ }^{3}$ \\ ${ }^{1,2,3}$ Department of Chemistry, Faculty of Science and Technology, Universitas Islam Negeri \\ Alauddin Makassar, Indonesia. 92113
}

\{sitti.chadijah@uin-alauddin.ac.id¹,bmaswaty@gmail.com²,pututkimia@gmail.com³\}

\begin{abstract}
Gelatine was a biopolymer of amino acid that obtained from the results of the hydrolysis of collagen. Materials that have potential as the raw material, the production of halal gelatine goat skin and bone are the goats. Aimed this research to know the optimum temperature in the halal gelatine production from waste of skin and bone of beans goat. Gelatine production process used A-type with hydrochloric acid $(\mathrm{HCl}) 3 \%$. The gelatine was extract in water bath with variations of temperature of $45^{\circ} \mathrm{C}, 55^{\circ} \mathrm{C}$ and $65^{\circ} \mathrm{C}$. Results of the analysis of the characterization of the physicochemical gelatine of skin of goat and goat bones. Showed that already meet the requirements of the National Standard (SNI), the which is the $\mathrm{pH}$ of the gelatine skin and bone goat (4.5 and 3.5), the value of the water content of goat skin and bone are $(10,29 \%$ and $3.25 \%)$ as well as the value of the values of goat skin and bone gelatine are $(2.75 \%$ and $1.04 \%$ out $)$. The results of the analysis of functional groups by using FTIR absorption showed a typical functional groups of gelatin that is $\mathrm{NH}$ and $\mathrm{OH}(3430.33 \mathrm{~cm}-1$ and $3359.56 \mathrm{~cm}$ $1), \mathrm{C}=\mathrm{O}(1644.48 \mathrm{~cm}-1$ and $1652.82 \mathrm{~cm} \mathrm{-1)}$ and $\mathrm{C}=\mathrm{N}(1244.64 \mathrm{~cm}-1$ and $1242.09 \mathrm{~cm}-1)$. The results of the fatty acids showed an oleic acid $(36.66 \%)$, palmitate acid (24.53\%), linoleic acid (15.28\%), stearic acid (10.60\%), Palmitoleic acid (2.24\%), myristic acid (1.60\%), margaric acid (0.84\%) and lauric acid $(0.20 \%)$.
\end{abstract}

Keywords: Biopolymer, FTIR, Gelatine, Goat Skin, Goat Bones.

\section{Introduction}

Indonesia has a high need for gelatine. Gelatine is a material that can be used both as food and non-food products. Gelatine is commonly used in the pharmaceutical, cosmetic and food photography as a foam-forming material, binders, stabilizers, and emulsifiers gel maker(Huda, Atmaka and Nurhartadi, 2013). A 90\% gelatin circulating in Indonesia are imported by the government. Gelatine imported mostly from China, Japan, Germany, France, Australia, India and New Zealand. But the problem is largely imported not only gelatin derived from cow skin and bones of cattle, but also from pig skin. The use of raw materials derived from pig skin became a major problem for the Indonesian people whose population is predominantly Moslem (Said et al., 2011).

Goats are animals that has many benefits, almost all of this part of the goat can be harnessed and used as ingredients that have economic value. Bagain parts of goat meat, skin, bones and dung is part of a goat which is often exploited. Goat farm began in circa 8000-7000 
$\mathrm{BC}$ in the West Asia region penggunangan. Goats can be classified into three groups based on the function of the goat that is, meat goat, dairy goat and goat dual-purpose. Currently in Indonesia there are several types of goats are bred like, marica goat, goat samosir, estuaries goat, goat ribs, goat Gembrong, ettawah crossbreed goats, goat beans and goat Bengal(Pamungkas et al., 2008). Protein Collagen is the most abundant protein found in the skin which ranged from $80 \%-90 \%$ of total protein(Asmi 2014). Cattle foot skin an animal waste that contains collagen is high at around $80 \%$ (Miwada et al., 2005). The skin is an organ that is quite heavy, amounting to $8-12 \%$ by weight of a goat(Rotinsulu et al., 2015). Collagen is the major structural protein in bones and skin of animals, collagen has a three $\alpha$-chains intertwined or collagen triple helix (Gómez-Guillén, Giménez and Montero, 2005). The production of Gelatine used acid hydrolysis and the wet ingredients with the extraction of high temperature with water, sterilization, and drying (Demirhan, Ulca and Senyuva, 2012).

Gelatine is a polypeptide by extraction of collagen from animals. Gelatine used for ingredient to enhance the elasticity, consistency and stability of product (Taheri et al., 2009). Gelatine is obtained from collagen found in bones, skin and connective tissue of animals. Gelatine is produced by extraction and hydrolyze collagen. Extraction and hydrolysis process causes protein denaturation of collagen triple helix arrangement into a single chain through a merger with three peptide bond so that the resulting compound gelatine(Fransiskha, 2016).

Broadly speaking, the gelatine has the following amino acid structure, -Ala-Gly-Pro-ArgGly-Glu-Gly-Pro-4Hyd. Gelatine has the structure of the amino acids proline, hydroxyproline, amino acids and amino acid glycine at the other (Syafiqoh, 2014)

\section{Material and Methods}

\section{Sample Preparation}

Goat skin into gelatine material, washed with clean running water. Then the skin was soaked in a mixture of water and Teepol solution of 1\% with a ratio of 3: 1 for 2 hours and washed again with running water until clean. Furthermore, soaked in a mixture of water, sodium sulfide $\left(\mathrm{Na}_{2} \mathrm{~S}\right)$ and lime solution $2 \%$ with a ratio of $3: 1: 1$ for 36 hours. Then washed again with water and neutralized with a solution of formic acid $(\mathrm{HCOOH}) 2 \%$ and water at a ratio of 3: 1 up to neutral $\mathrm{pH}$ (7-7.5). Furthermore, the skin cut into small pieces with a size of $3 \times 3 \mathrm{~cm}$ (Said et $a l ., 2011)$. The goat bone gelatine material, washed with water until the fat and meat despite everything. Then cut into small pieces with a size of $\pm 3 \mathrm{~cm}$ (Juliasti, Legowo and Pramono, 2015).

\section{Curing Process}

The curing process is done by soaking the skin and bones of goats as much as 100 grams into each solution of hydrochloric acid $(\mathrm{HCl}) 3 \%$ with a ratio of $1: 5(\mathrm{w} / \mathrm{v})$ for 36 hours. Then the bones and skin are washed by using distilled water until a neutral $\mathrm{pH}$ value (Rahayu and Fithriyah, 2015).

\section{Gelatine production}

Gelatine production is done by the method of extraction, the skin and the bones that have passed through the curing process each put in a glass beaker and add distilled water in the ratio 1: $2(\mathrm{w} / \mathrm{v})$. The temperature and time used in the extraction stage $45^{\circ} \mathrm{C}, 55^{\circ} \mathrm{C}$ and $65^{\circ} \mathrm{C}$ for 5 hours. Then the extraction was filtered and dried freeze dryer. Then dry gelatin that has been smoothed to obtain gelatine powder (Rahayu and Fithriyah, 2015). 


\section{Physicochemical properties testing Gelatine}

a. Rendamen

Rendamen calculation is done by comparing the weight of gelatin by weight of gelatin raw materials by using the formula:

$$
\text { Rendamen }(\%)=\frac{\text { Weight of Gelatin }}{\text { Weight of Raw Material Gelatin }} \times 100 \%
$$

b. Test the $\mathrm{pH}$ value

Test the $\mathrm{pH}$ value of the gelatine is done by weighing 0.5 gram sample is then dissolved in $20 \mathrm{~mL}$ of distilled water and homogenized. Further samples were tested with a calibrated $\mathrm{pH}$ meter (Said et al., 2011)

c. Assay Test Water

Test the water content in the gelatine was conducted by AOAC (Association of Analytical Chemist Office). Beaker weighed and dried in an oven at $105^{\circ} \mathrm{C}$ for 1 hour. Then gelatine weighed as much as 0.5 grams, then put in a beaker and dried in at a temperature of $105^{\circ} \mathrm{C}$ for 1 hour until a constant weight of gelatine obtained. Furthermore, cooled in a desiccator for 15 minutes.

\section{d. Assays Abu}

Ash content test was conducted by AOAC (Association of Analytical Chemist Office). The results of the analysis of water content is heated in a furnace to a temperature of $660{ }^{\circ} \mathrm{C}$ for \pm 3 hours to ashes. After that weighed the weight of the cup and the weight of gelatin.

\section{Characterization of Functional Groups by FTIR}

Functional group analysis was conducted using FTIR spectroscopy with KBr pellets, where a sample of 0.5 grams of powdered gelatin pellets are mixed with $\mathrm{KBr}$ in the ratio 1: 8 . Then, the mixture is compressed in a mold with the aid of a hydraulic pump to be a thin plate. Further samples of thin plate Shimidzu identified with FTIR spectrometer with a wavelength of 4000$500 \mathrm{~cm}-1$ (Puspawati, Simpen and Miwada, 2012).

\section{Analysis of the content of fatty acid by $G C-M S$}

As many as $1 \mu \mathrm{L}$ samples of fat that has been injected into the diesterifikasi column GC-MS method with autosampler. Then the separation is carried out in a column of RTx 1-MS Restech, $30 \mathrm{~m} \times 0.25 \mathrm{~mm}$ ID $0.25 \mu \mathrm{m}$, with a silent phase of Poly dymethil xiloxan, using the injector temperature $280^{\circ} \mathrm{C}$, column temperature of $70^{\circ} \mathrm{C}$ which raised to $300^{\circ} \mathrm{C}\left(10{ }^{\circ} \mathrm{C} /\right.$ minute $)$ and flow rate $1.15 \mathrm{~mL} /$ minute. The detector used is MS Multifier Electron Detector (EMD) $70 \mathrm{MeV}$. The results of the analysis are compared to the standard data contained on GC-MS postrun software analysis(Hermanto, Muawanah and Harahap, 2018).

\section{Results and Discussion}

\section{Gelatin Physicochemical Analysis}

This study was conducted using raw materials of goat skin and goat bones are still in a fresh state and good for maintaining the quality of the resulting gelatin. Hydrolysis process is done by using a solution of hydrochloric acid $(\mathrm{HCl}) 3 \%$. Tests carried out in this research is to test 
rendamen value, moisture content, ash content, $\mathrm{pH}$ value and the functional group by using FTIR.

Based on the physicochemical analysis of goat skin and bone gelatin goat obtained the results as shown in Table 1

Table 1. Physicochemical Analysis Results Goat Skin Gelatine

\begin{tabular}{cccccccc}
\hline \multirow{2}{*}{ No. } & $\begin{array}{c}\text { Physicochemical } \\
\text { analysis }\end{array}$ & \multicolumn{3}{c}{ Goat skin } & \multicolumn{3}{c}{ Goat bones } \\
\cline { 3 - 7 } & $\mathbf{4 5} \mathbf{5}^{\circ} \mathbf{C}$ & $\mathbf{4 5}^{\circ} \mathbf{C}$ & $\mathbf{5 5}^{\circ} \mathbf{C}$ & $\mathbf{6 5}^{\circ} \mathbf{C}$ & $\mathbf{5 5}^{\circ} \mathbf{C}$ & $\mathbf{6 5}^{\circ} \mathbf{C}$ \\
\hline 1 & $\begin{array}{c}\text { The pH value } \\
\text { Rendamen value } \\
(\%)\end{array}$ & 4.6 & 3.7 & 3.6 & 3.5 & 4.3 & 4.5 \\
3 & 2,32 & 2.11 & 2,22 & 2.46 & 2,49 & 2,54 \\
3 & $\begin{array}{c}\text { Value Water } \\
\text { Content (\%) }\end{array}$ & 10.65 & 3.75 & 3.37 & 3.25 & 10,30 & 10.29 \\
4 & $\begin{array}{c}\text { Abu Kadar value } \\
(\%)\end{array}$ & 8.23 & 1.73 & 1.44 & 1.04 & 7,60 & 1.50 \\
\hline
\end{tabular}

Based on the analysis rendamen values obtained, the temperature at the extraction stage to give effect to rendamen value obtained. Based on the data obtained, the optimum temperature of making gelatin kult sheep and goat bones at a temperature of $65^{\circ} \mathrm{C}$. It can be seen from the results rendamen value where the higher the temperature used, the higher the value rendamen obtained. This is confirmed by the statement(Sompie et al., 2017), that a high temperature in the extraction stage will increase the value of the yield of the resulting gelatin. The high temperatures facilitate breaking the hydrogen bonds in the collagen that magnifies dissolution of collagen in the extraction process that increases the production of gelatin.

Based on research, the $\mathrm{pH}$ value of the skin gelatine goat and goat bones is obtained that is 3.9 to 4.6. Low $\mathrm{pH}$ values obtained for the immersion process which uses an acid solution. The results obtained showed that the gelatin production is quite good, because the $\mathrm{pH}$ value obtained according to the $\mathrm{pH}$ value of the gelatin based GMIA standard 3.8 to 6.0(Sompie et al., 2017). Gelatine with a low $\mathrm{pH}$ value is well used in the food industry as sour syrup, mayonnaise, and juice drink products (Juliasti, Legowo and Pramono, 2015)

Based on the results obtained by the value of the ash content in goat skin gelatine with successive extraction temperature $45^{\circ} \mathrm{C}, 55^{\circ} \mathrm{C}$ and $65^{\circ} \mathrm{C}$ which is $2.6 \%, 2.8 \%$ and $1.5 \%$. While the ash content in goat bone gelatin with successive extraction temperature of $45{ }^{\circ} \mathrm{C}, 55^{\circ} \mathrm{C}$ and $65^{\circ} \mathrm{C}$ which is $1.7 \%, 1.4 \%$ and $1.04 \%$. Based on the ash content values obtained, the production of goat skin and bone gelatin is compliant is based on ISO stating that the maximum ash content is $3.25 \%$ (Said et al., 2011)

Based on the results obtained by the value of the water content of the gelatine goatskin with extraction temperature $45^{\circ} \mathrm{C}, 55^{\circ} \mathrm{C}$ and $65^{\circ} \mathrm{C}$ respectively ie, $10.65 \%, 10.30 \%$ and $10.29 \%$. As for the goat bone gelatine with extraction temperature $45^{\circ} \mathrm{C}, 55^{\circ} \mathrm{C}$ and $65^{\circ} \mathrm{C}$ respectively ie, $3.75 \%, 3.37 \%$ and $3.25 \%$. Based on the water content value obtained for gelatine production of goat leather and goat bones meet the requirements which according to SNI No. 06-3735 1995 water content for maximum gelatine worth 16\%(Rosentadewi, 2015). 
Characterization of Functional Groups Gelatine with FTIR

The comparison analysis of the characteristics of goat skin and bone gelatine temperature of $45^{\circ} \mathrm{C}, 55^{\circ} \mathrm{C}$ and $65^{\circ} \mathrm{C}$ can be seen in Table 2, Table 3 and Table 4.

Table 2. Analysis of Functional Groups Gelatin Goat Goat Skin and Bones Temperature $45^{\circ} \mathrm{C}$

\begin{tabular}{|c|c|c|c|}
\hline \multicolumn{3}{|c|}{ Absorption peaks $\left(\mathrm{cm}^{-1}\right)$} & \multirow[b]{2}{*}{ Functional groups } \\
\hline $\begin{array}{l}\text { Goat Skin } \\
\text { Gelatine }\end{array}$ & $\begin{array}{l}\text { Bone Gelatine } \\
\text { Goat }\end{array}$ & $\begin{array}{c}\text { gelatine } \\
\text { Commercial }\end{array}$ & \\
\hline 3433.54 & 3367.42 & 3449.23 & $\mathrm{OH}, \mathrm{NH}$ secondary amide, \\
\hline 2961.50 & 2960.77 & 2934.01 & Aliphatic C-H2 \\
\hline 1639.31 & 1653.47 & 1654.62 & $\begin{array}{l}\mathrm{C}=\mathrm{O} \text { stretching of a secondary } \\
\text { amide }\end{array}$ \\
\hline 1544.83 & 1543.22 & 1544.72 & $\begin{array}{l}\text { carboxylic acid salt and } \mathrm{CN} \\
\text { stretching }\end{array}$ \\
\hline 1243.74 & 1242.07 & 1243.36 & $\begin{array}{l}\mathrm{NH} \text { bending ( } \mathrm{CN} \text { helping } \\
\text { amine) }\end{array}$ \\
\hline 1080.66 & 1080.67 & 1081.49 & $\begin{array}{l}\text { Aromatic } \mathrm{CH} \text { bending and } \mathrm{CO} \\
\text { Stretching }\end{array}$ \\
\hline
\end{tabular}

Table 3. Analysis of Functional Groups Gelatine Goat Goat Skin and Bones Temperature

\begin{tabular}{|c|c|c|c|}
\hline \multicolumn{3}{|c|}{ Absorption peaks $\left(\mathrm{cm}^{-1}\right)$} & \multirow[b]{2}{*}{ Functional groups } \\
\hline $\begin{array}{l}\text { Goat Skin } \\
\text { Gelatine }\end{array}$ & $\begin{array}{c}\text { Bone Gelatin } \\
\text { Goat }\end{array}$ & $\begin{array}{c}\text { gelatine } \\
\text { Commercial }\end{array}$ & \\
\hline 3432.40 & 3400.70 & 3449.23 & $\mathrm{OH}, \mathrm{NH}$ secondary amide, \\
\hline 2964.08 & 2960.34 & 2934.01 & Aliphatic C-H2 \\
\hline 1653.78 & 1652.84 & 1654.62 & $\begin{array}{l}\mathrm{C}=\mathrm{O} \text { stretching of a secondary } \\
\text { amide }\end{array}$ \\
\hline 1545.12 & 1543.36 & 1544.72 & $\begin{array}{l}\mathrm{C}=\mathrm{O} \text { asymmetry of the } \\
\text { carboxylic acid salt, } \mathrm{CN} \\
\text { stretching and bending } \mathrm{CH} 2\end{array}$ \\
\hline 1244.99 & 1242.43 & 1243.36 & $\begin{array}{l}\mathrm{NH} \text { bending (CN helping } \\
\text { amine) }\end{array}$ \\
\hline 1081.07 & 1080.61 & 1081.49 & $\begin{array}{l}\text { Aromatic } \mathrm{CH} \text { bending and } \mathrm{CO} \\
\text { Stretching }\end{array}$ \\
\hline
\end{tabular}

Table 4. Analysis of Functional Groups Gelatine Goat Goat Skin and Bones Temperature $65^{\circ} \mathrm{C}$

\begin{tabular}{|c|c|c|c|}
\hline \multicolumn{3}{|c|}{ Absorption peaks $\left(\mathrm{cm}^{-1}\right)$} & \multirow[b]{2}{*}{ Functional groups } \\
\hline $\begin{array}{l}\text { Skin gelatine } \\
\text { Goat }\end{array}$ & $\begin{array}{c}\text { Bone Gelatine } \\
\text { Goat }\end{array}$ & $\begin{array}{c}\text { Gelatine } \\
\text { Commercial }\end{array}$ & \\
\hline 3425.06 & 3310.58 & 3449.23 & $\mathrm{OH}, \mathrm{NH}$ secondary amide, \\
\hline 2960.62 & 2959.52 & 2934.01 & Aliphatic C-H2 \\
\hline 1640.36 & 1652.15 & 1654.62 & $\begin{array}{l}\mathrm{C}=\mathrm{O} \text { stretching of a secondary } \\
\text { amide }\end{array}$ \\
\hline
\end{tabular}




\begin{tabular}{llll}
\hline 1545.34 & 1539.34 & 1544.72 & $\begin{array}{l}\mathrm{C}=\mathrm{O} \text { asymmetry of the } \\
\text { carboxylic acid salt, CN } \\
\text { stretching and bending CH2 }\end{array}$ \\
1245.20 & 1241.77 & 1243.36 & $\begin{array}{l}\text { NH bending (CN helping amine) } \\
\text { CO aromatic CH bending and } \\
\text { stretching of the secondary alcohol }\end{array}$ \\
\hline
\end{tabular}

Testing the absorption characteristics of gelatine functional groups with FTIR method is very important. This is because the results of the characteristic functional groups can describe the success of the production of gelatin. FTIR testing methods with the help of infrared light that is fired into a material for the detection of functional groups contained in the material. Wherein each group has the function of absorption frequency range that is based on the absorption range can be identified functional groups present in a material at a specific infrared spectrum.

Based on the research results, the spectrum of functional groups on the gelatine has the structure of the hydroxyl functional group $(\mathrm{OH})$, carbonyl $(\mathrm{C}=\mathrm{O})$ and the amine group $(\mathrm{NH})$. This shows that gelatine derived from protein.

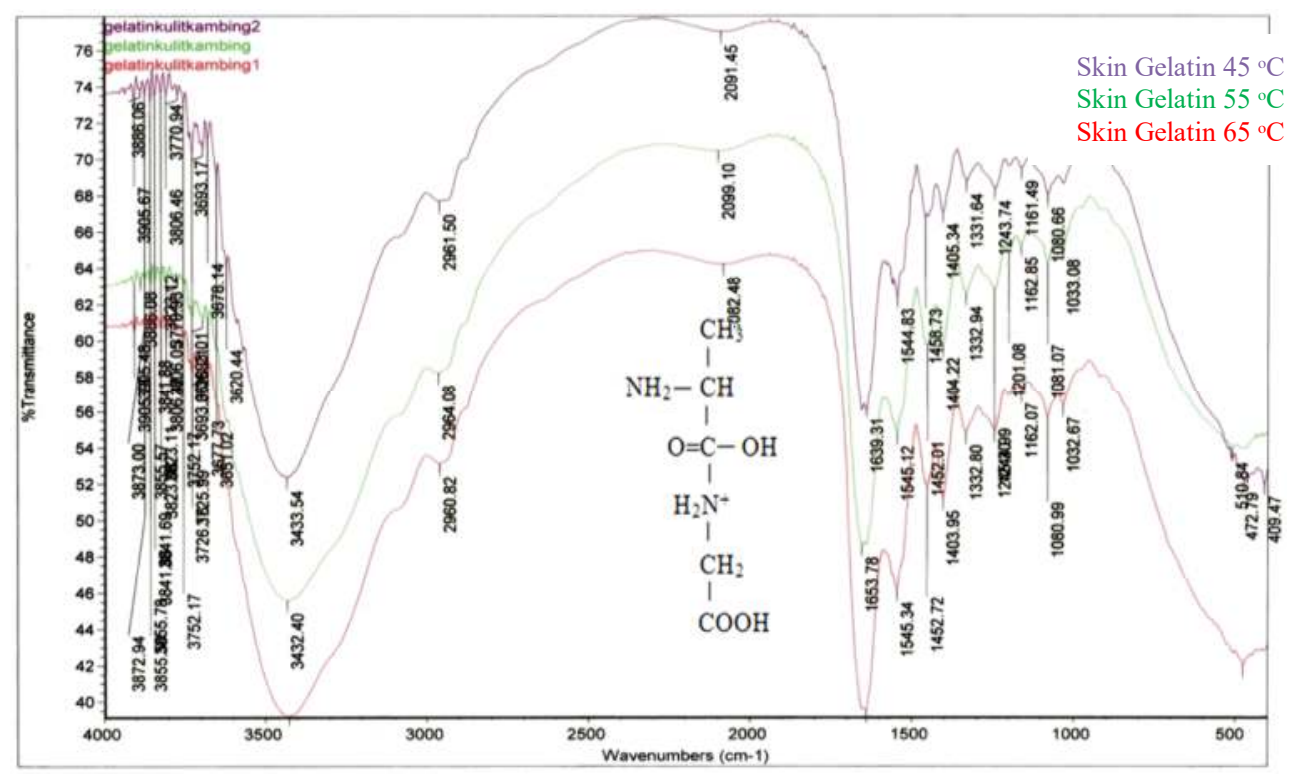

Figure 1. Result Analysis of Functional Groups Goat Skin Gelatine

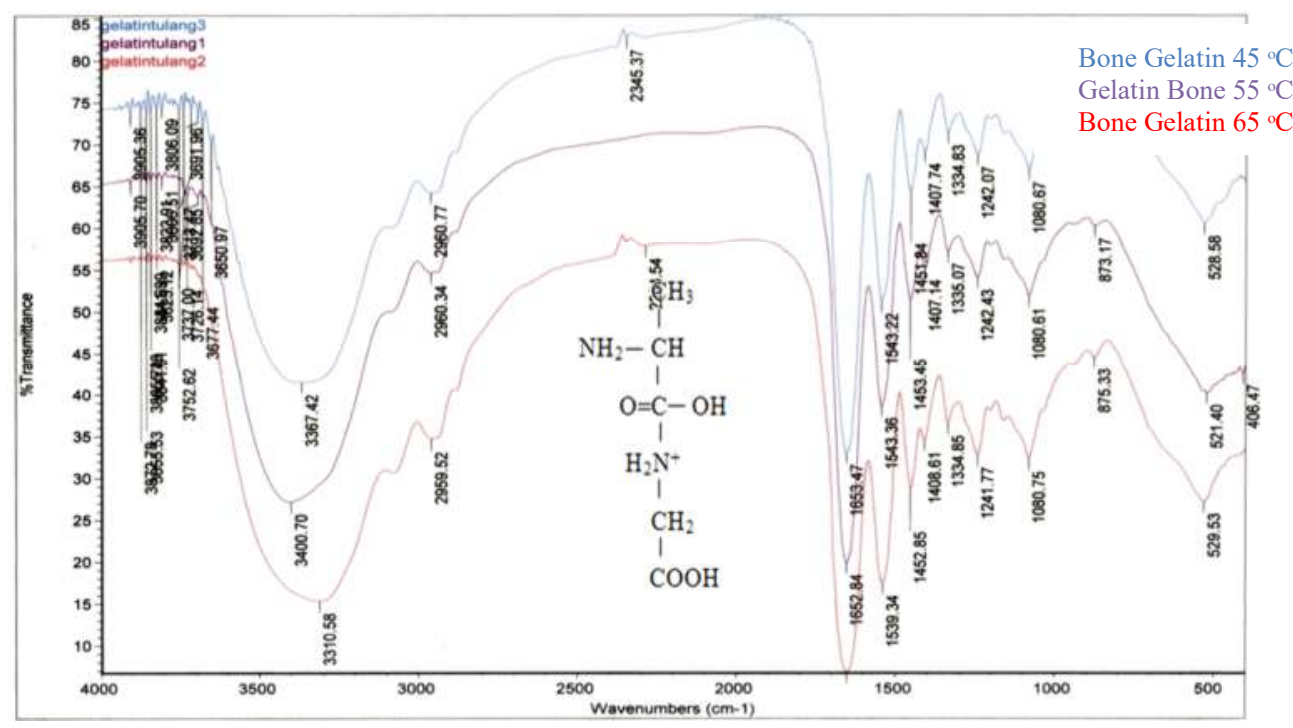


Figure 2.Result Analysis of Functional Groups Goat Bone Gelatine

Based on the analysis of the resulting spectrum can be seen that the absorption spectrum between the functional groups of goat skin and bone gelatin goat beans at a temperature $45^{\circ} \mathrm{C}$, $55^{\circ} \mathrm{C}$ and $65^{\circ} \mathrm{C}$ have in common are almost identical like on the Figure 1 and figure 2. However, differences in temperature used in the manufacture of gelatine shows the differences in the absorption spectrum produced. At a temperature of $45^{\circ} \mathrm{C}$ there are many unwanted pick spectrum. Meanwhile, at a temperature of $55^{\circ} \mathrm{C}$ produces a spectrum of unwanted pick less. And at a temperature of $65^{\circ} \mathrm{C}$ produces a spectrum of unwanted pick less than other temperature that is used. The results of the analysis of functional groups on goat skin gelatine contained many impurities such as salts or organometallic compounds characterized by the number of pick spectrum. This is due to factors of production such gelatin.

\section{Fatty Acid Composition Analysis by GC-MS}

Analysis using GC-MS instrument used to determine the content of fatty acids contained in goat bone. Results of analysis fatty acids by GC-MS can be seen in Table 5

Table 5. Analysis of Fatty Acid Composition of Goat Bones

\begin{tabular}{ccc}
\hline Retention time (s) & Broad peak (\%) & prediction Components \\
\hline 22007 & 36.66 & Oleic acid \\
20,318 & 24.53 & Palmitate acid \\
21944 & $15: 28$ & Linoleic acid \\
22188 & 10.60 & Stearic acid \\
20112 & $2: 24$ & Palmitoleinat acid \\
18,216 & 1.60 & Myristic acid \\
21,256 & 0.84 & Margarat acid \\
15895 & $0: 20$ & Lauric acid \\
\hline
\end{tabular}

GC-MS analysis is a method of separation of organic compounds using two methods of analysis of compounds which gas chromatography to analyze the amount of compound quantitatively and mass spectrometry to analyze the molecular structure of the analyte compound. At GC number appears in the chromatogram peak that indicates the number of components contained in the bone.

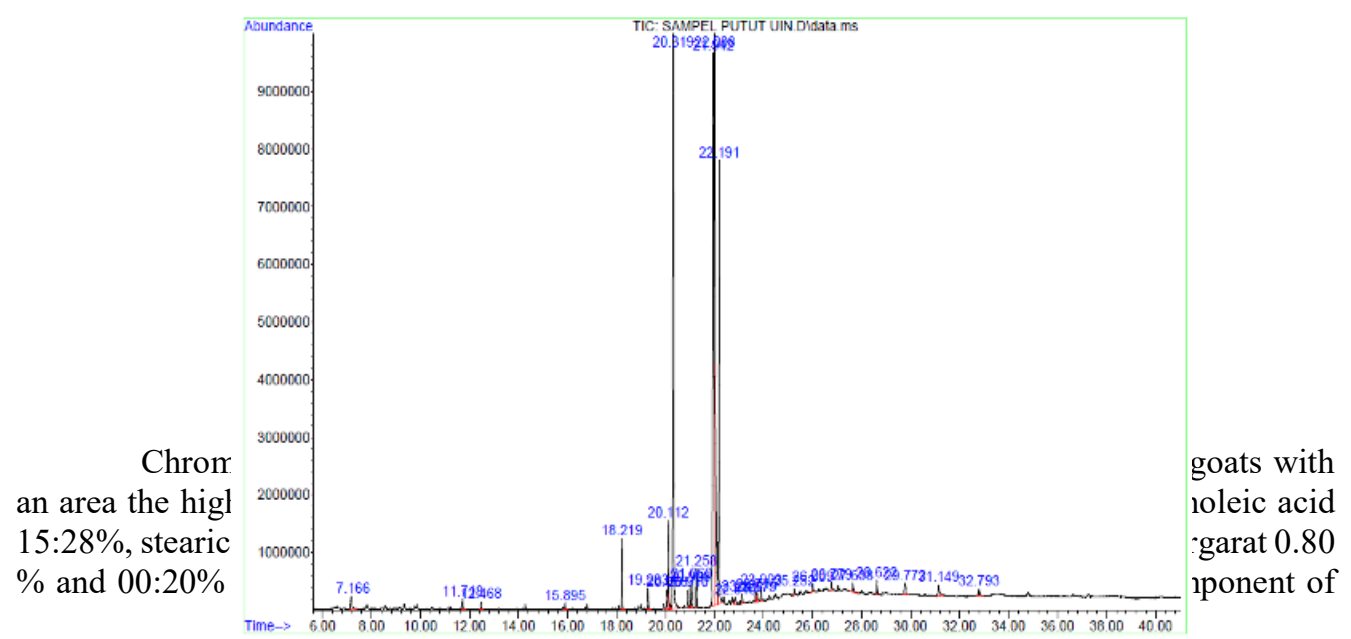


the fatty acid found in goat bone, among others, capric acid, lauric acid, myristic acid, palmitic acid, palmitoleic acid, stearic acid, oleic acid and linoleic acid.

\section{Conclusion}

Based on the research that has been done, it can be concluded:

1. The optimum temperature in the extract of goat skin and bones of goats is $65{ }^{\circ} \mathrm{C}$ with rendamen obtained at $2.54 \%$ for goat skin gelatin and $2.46 \%$ for goat bone gelatine.

2. FTIR characterization of goat skin and bone gelatine showed a typical absorption of functional groups of gelatine were characterized by the presence of hydroxyl functional group $(\mathrm{OH})$, carbonyl $(\mathrm{C}=\mathrm{O})$ and the amine group $(\mathrm{NH})$.

3. Fatty acid content of the most dominant in the bones of goats among others, palmitic acid, linoleic acid, stearic acid, palmitoleinat acid, myristic acid, margarat acid and lauric acid.

\section{References}

[1] Demirhan, Y., Ulca, P. and Senyuva, H. Z. (2012) "Detection Of Porcine DNA In Gelatine And Gelatine-Containing Processed Food Products-Halal”, Meat Science. Elsevier Ltd, 90(3), pp. 686-689. doi: 10.1016/j.meatsci.2011.10.014.

[2] Fransiskha, T. (2016) "Optimasi Ekstraksi Gelatin dari Tulang Ikan Tuna ( Thunnus albacares )”, Jurnal WIYATA, 3(1), pp. 11-16.

[3] Gómez-Guillén, M. C., Giménez, B. and Montero, P. (2005) "Extraction Of Gelatin From Fish Skins By High Pressure Treatment”, Food Hydrocolloids, 19(5), pp. 923928. doi: 10.1016/j.foodhyd.2004.12.011.

[4] Hermanto, S., Muawanah, A. and Harahap, R. (2018) "Profil dan Karakteristik Lemak Hewani (Ayam, Sapi dan Babi) Hasil Analisa FTIR dan GCMS”, Jurnal Kimia VALENSI, 1(3), pp. 102-109. doi: 10.15408/jkv.v1i3.219.

[5] Huda, W., Atmaka, W. and Nurhartadi, E. (2013) "Kajian Karakteristik Fisik dan Kimia Gelatin Ekstrak Tulang Kaki Ayam (Gallus gallus bankiva) dengan Variasi Lama Perendaman dan Konsentrasi Asam”, Jurnal Teknosains Pangan, 2(3), pp. 7075. doi: 10.1007/s11412-008-9054-4.

[6] Juliasti, R., Legowo, A. M. and Pramono, Y. B. (2015) "Pemanfaatan Limbah Tulang Kaki Kambing sebagai Sumber Gelatin dengan Perendaman Menggunakan Asam Klorida”, Jurnal Aplikasi Teknologi Pangan, 04(01), pp. 5-10. doi: 10.17728/jatp.2015.01.

[7] Miwada, I. S. et al. (2005) "Karakteristik Gelatin dari Kulit Kaki Ternak dan Potensinya Sebagai Edible Film”, Majalah Ilmiah Peternakan, 18, pp. 109-113.

[8] Nur, A. (2014) "Pengaruh Perbedaan Bagian Kulit dan pH Larutan Perendam Jeruk Nipis (Citrus Aurantifolia) Terhadap Kuantitas dan Kualitas Kerupuk Kulit Kerbau” Skripsi. Makassar: Fakultas Peternakan Universitas Hasanuddin.

[9] Pamungkas, F. A. et al. (2008) Potensi Plasma Lokal 2008 Indonesia. Sumatera Utara: Pusat Penelitian dan Pengembangan Peternakan.

[10] Puspawati, N. M., Simpen, I. N. and Miwada, I. N. S. (2012) "Isolasi Gelatin Dari Kulit Kaki Ayam Broiler Dan Karakterisasi Gugus FUngsinya Dengan Spektrofotometri FTIR", 6(1), pp. 79-87.

[11] Rahayu, F. and Fithriyah, N. H. (2015) "Pengaruh Waktu Ekstraksi Terhadap Rendemen Gelatin dari Tulang Ikan Nila Merah", Prosiding Semnastek, (November), pp. $1-6$.

[12] Rosentadewi, A. (2015) "Ekstraksi dan Karakterisasi Gelatin Kulit Kambing 
Peranakan Etawah Menggunakan Hidrolisis Asam Asetat pada Kulit yang Mengalami Proses Buang Bulu Secara Pemanasan."BS thesis. Jakarta: UIN Syarif Hidayat Tullah.

[13] Rotinsulu, M. D. et al. (2015) "Pengamatan Post-Mortem Kualitas Kulit Kambing Di Kota Manado", LPPM Bidang Sains dan Teknologi, 2, pp. 82-89.

[14] Said, M. I. et al. (2011) "Karakteristik Gelatin Kulit Kambing Yang Diproduksi Dengan Proses Asam Dan Basa”, 31(3), pp. 190-200.

[15] Sompie, M. et al. (2017) "Pengaruh Umur Potong dan Konsentrasi Larutan Asam Asetat terhadap Sifat Fisik dan Kimia Gelatin Kulit Babi”, Sains Peternakan, 10(1), p. 15. doi: 10.20961/sainspet.10.1.15-22.

[16] Syafiqoh, F. (2014) "Analisis Gelatin Sapi dan Gelatin Babi Pada Produk Cangkang Kapsul Keras Obat dan Vitamin Menggunakan FTIR dan KCKT”, Skripsi, (September), pp. 2-107.

[17] Taheri, A. et al. (2009) "Extraction And Physicochemical Characterization Of Greater Lizardfish (Saurida Tumbil) Skin And Bone Gelatin”, Journal of Food Science, 74(3), pp. 160-165. doi: 10.1111/j.1750-3841.2009.01106.x. 